\title{
Analysis of Radio Management based on the Natural Ecosystem Theory
}

\author{
CHEN Jiajia ${ }^{1}$, LIU Bin ${ }^{1 *}$, QIAN Zhaojun ${ }^{1}$ \\ 1.State Radio Monitoring Center, Beijing \\ chenjiajia@srrc.org.cn, Liubin@srrc.org.cn, qianzhaojun@srrc.org.cn
}

\begin{abstract}
This paper introduces and analyzes the $5 \mathrm{G}$
industry ecosystem by means of ecological research. On the basis

of the analysis of the elements, structure and function of the $5 \mathrm{G}$

industry ecosystem, the position and function of radio

management in the $5 \mathrm{G}$ industry ecosystem are discussed. In order

to better develop the function of radio management in the new

era condition, the paper creatively gives a view that using

ecosystem consciousness to strengthen the radio management,

then maintaining the order of radio waves, promotes the healthy

development of the $5 \mathrm{G}$ industry ecosystem.
\end{abstract}

Keywords-radio management, communication industry, ecosystem

\section{INTRODUCTION}

The research and development of the fifth generation mobile communication (5G) system for 2020 and the future has been carried out in full swing all over the world. Compared with previous mobile communication systems, $5 \mathrm{G}$ is not only based on the mobile communication industry itself, to achieve a bridge of information communication, but also with the Internet of Things, industrial Internet and vehicle networking and other areas of integration and development, resulting in massive access and extremely fast rate requirements, resulting in explosive growth of network pipeline traffic.

Every enterprise in the $5 \mathrm{G}$ industry is a living organism, competing, co-operating and promoting itself to adapt to the changing environment, all of which are experienced, growing, and even perished. The research on the development and

${ }^{*}$ Corresponding author evolution of the $5 \mathrm{G}$ industry has a great similarity with the study of the natural ecosystem, and the natural ecosystems have formed a powerful and perfect systems in the process of long Millennium evolution and natural selection. It has a powerful ability to adapt to the external changes and can be efficient to use material and energy to further strengthen their vitality. Therefore, based on this similar relationship, using the theory of mature development in ecology to analyze $5 \mathrm{G}$ industry and its components can get useful inspiration from the different perspectives [1].

Based on the the similarity of the competition and cooperation between the communication enterprises and the evolutionary process of the natural ecosystem, this paper analyzes the elements, structures, functions and their relations between the $5 G$ industry ecosystem by using the concepts, principles and methods of ecology. By using the viewpoint of ecology, we focus on the analysis of how to strengthen radio management, explore the use of ecological methods to promote the management system of radio management and governance under the background of the new era.

\section{ANALYSIS OF THE STRUCTURE OF THE 5 G INDUSTRY}

\section{ECOSYSTEM}

Natural ecosystem refers to the unified whole of various biological communities (biological factors) and environmental (non-biological factors) in a certain time and space, such as animals, plants and microorganisms. In this unified whole, the flow of species, energy, material, and information are carried out among the elements, interacting with the environment, restricting each other to form a complex of self-regulating functions, and keeping in a relatively stable state within a certain period of time.

Analogous to the natural ecosystem, the $5 \mathrm{G}$ industry ecosystem can be defined as a unified whole of the 
communication enterprises, users, markets and other communication communities (biological factors) and the environment (natural resources, social environment, economic culture, laws and regulations, etc.) in a certain period and space. In a unified whole, the elements of each component are composed of material circulation, energy flow, currency circulation, information transfer, knowledge exchange, technology diffusion and production activities. They interact with the environment and restrict each other to form a complex of self-regulating functions, and keeping in a relatively stable state within a certain period of time.

The comparison between the $5 \mathrm{G}$ industry ecosystem and the natural ecosystem in the components, structures and functions, the evolution process, and the characteristics of the system, is shown in Table 1 . Table 1 lists the similarity contrast [2] between two systems.

TABLE I. COMPARATIVE ANALYSIS OF STRUCTURAL SIMILARITIES BETWEEN 5G INDUSTRY AND NATURAL ECOSYSTEM

\begin{tabular}{|c|c|c|c|}
\hline \multicolumn{2}{|c|}{ Similarities } & natural ecosystem & $5 G$ industry \\
\hline \multirow[t]{2}{*}{ components } & $\begin{array}{l}\text { biological } \\
\text { factors }\end{array}$ & Bio-diversity & Enterprise diversity \\
\hline & $\begin{array}{l}\text { non-biological } \\
\text { factors }\end{array}$ & Sunshine, air, water, soil, etc & $\begin{array}{l}\text { Natural resources, social environment, economic } \\
\text { culture, laws and regulations, etc. }\end{array}$ \\
\hline \multirow{2}{*}{$\begin{array}{l}\text { Relationship } \\
\text { between } \\
\text { components }\end{array}$} & $\begin{array}{l}\text { biology and } \\
\text { non-biology }\end{array}$ & $\begin{array}{l}\text { Animals, plants, microbes interact with } \\
\text { their environment and each other. }\end{array}$ & $\begin{array}{l}\text { A large number of enterprises and institutions } \\
\text { interact with their environment and each other. }\end{array}$ \\
\hline & $\begin{array}{l}\text { between } \\
\text { biological } \\
\text { populations }\end{array}$ & $\begin{array}{l}\text { Competition, predation, parasitism, } \\
\text { neutrality, symbiosis and reciprocity. }\end{array}$ & $\begin{array}{l}\text { Competition, merger, parasitism, neutrality, } \\
\text { symbiosis, cooperation and reciprocity. }\end{array}$ \\
\hline \multirow[t]{2}{*}{$\begin{array}{l}\text { Structural } \\
\text { similarity }\end{array}$} & Entirety & $\begin{array}{l}\text { Animals, plants, microbes, natural } \\
\text { resources constitute a whole, and affect } \\
\text { each other. }\end{array}$ & $\begin{array}{l}\text { Enterprises, governments, natural resources } \\
\text { constitute a whole. Enterprises in the system are } \\
\text { influenced by other components. }\end{array}$ \\
\hline & $\begin{array}{l}\text { Time and space } \\
\text { characteristics }\end{array}$ & $\begin{array}{l}\text { Time and space scale are important factors } \\
\text { affecting ecosystem research. }\end{array}$ & $\begin{array}{l}\text { There are great differences in time, region, } \\
\text { industrial structure and development strategy. }\end{array}$ \\
\hline \multicolumn{2}{|c|}{ Value structure } & food chain, food net & value chain, value net \\
\hline \multicolumn{2}{|l|}{ Function } & $\begin{array}{l}\text { Species flow, energy flow, material cycle, } \\
\text { information transmission, value flow, } \\
\text { biological production, and resource } \\
\text { decomposition. }\end{array}$ & $\begin{array}{l}\text { Material flow, information dissemination, value } \\
\text { circulation, capital flow, production activities } \\
\text { and resource allocation }\end{array}$ \\
\hline \multicolumn{2}{|c|}{ hierarchical system } & $\begin{array}{l}\text { ecosystem, community, population, } \\
\text { individual }\end{array}$ & $\begin{array}{l}\text { Communication industry, enterprise cluster, } \\
\text { similar enterprises and individual enterprises }\end{array}$ \\
\hline \multicolumn{2}{|c|}{$\begin{array}{l}\text { Environmental impact and } \\
\text { adaptation }\end{array}$} & $\begin{array}{l}\text { Natural selection, survival of the fittest, } \\
\text { self-adaptive }\end{array}$ & $\begin{array}{l}\text { Survival of the fittest, survival of the fittest, } \\
\text { self-adaptive }\end{array}$ \\
\hline \multicolumn{2}{|c|}{ Evolutionary process } & $\begin{array}{l}\text { Generation, formation, development, } \\
\text { evolution }\end{array}$ & Generation, formation, development, evolution \\
\hline \multicolumn{2}{|c|}{$\begin{array}{l}\text { Evolutionary approach and } \\
\text { adaptation }\end{array}$} & $\begin{array}{l}\text { Gene mutation, foreign gene inflow (gene } \\
\text { exchange between populations, population } \\
\text { fusion), organisms change their structure } \\
\text { and behavior to adapt to their living } \\
\text { environment. }\end{array}$ & $\begin{array}{l}\text { Knowledge accumulation, technological } \\
\text { innovation and the absorption of external factors } \\
\text { (merger and integration among enterprises) can } \\
\text { change the environment to suit their needs while } \\
\text { adapting to the environment. }\end{array}$ \\
\hline \multicolumn{2}{|c|}{$\begin{array}{l}\text { Information } \\
\text { transmission }\end{array}$} & Genetic transmission & Knowledge transfer \\
\hline \multicolumn{2}{|c|}{ The motivation of evolution } & natural selection & $\begin{array}{l}\text { Environmental change, market competition, } \\
\text { technological innovation }\end{array}$ \\
\hline \multicolumn{2}{|c|}{ Evolutionary trend } & $\begin{array}{l}\text { The evolution of the state of the top } \\
\text { communities, the maximization of } \\
\text { biodiversity and total biomass, and the } \\
\text { enhancement of self adaptability. }\end{array}$ & $\begin{array}{l}\text { From the unstable state of traditional } \\
\text { industrialization to a stable and harmonious } \\
\text { ecological economic state, self competitiveness } \\
\text { is strengthened. }\end{array}$ \\
\hline
\end{tabular}


The three basic functional groups in the biological components of the natural ecosystem are producers (plants and certain microorganisms), consumers (animals and certain microorganisms) and decomposer, and non-biological functional groups are natural environment. The biological components of the $5 \mathrm{G}$ industry ecosystem can also be divided into producers (users), consumers (communication enterprises) and decomposers (market), and non biological functional groups are natural and social environment. Table 2 lists the comparative analysis of the functional groups of the two systems. Figure 1 shows the relationship between the functional groups of the $5 \mathrm{G}$ industry ecosystem.

TABLE II. COMPARATIVE FUNCTION ANALYSIS OF 5G INDUSTRY AND NATURAL ECOSYSTEM

\begin{tabular}{|c|c|c|c|c|}
\hline & & & natural ecosystem & $5 \mathrm{G}$ industry \\
\hline \multirow[t]{6}{*}{ Bio-components } & \multirow[t]{2}{*}{ Producer } & constitution & Green plants & Users \\
\hline & & function & $\begin{array}{l}\text { Organic compounds are } \\
\text { synthesized by photosynthesis } \\
\text { and provide energy for other } \\
\text { members of the ecosystem. }\end{array}$ & $\begin{array}{l}\text { Through its own demand, a new energy } \\
\text { flow, such as material flow, information } \\
\text { flow, knowledge flow, technology flow and } \\
\text { capital flow, can be formed to provide } \\
\text { energy for the production and management } \\
\text { of the related enterprises in the ecosystem. }\end{array}$ \\
\hline & \multirow[t]{2}{*}{ Consumer } & Constitution & animal & Communication company \\
\hline & & function & $\begin{array}{l}\text { Depending on the organic } \\
\text { matter produced by the } \\
\text { producers, the primary products } \\
\text { are processed and reproduced. }\end{array}$ & $\begin{array}{l}\text { Depending on the energy that the user } \\
\text { provides, such as material flow, } \\
\text { information flow, knowledge flow, } \\
\text { technology flow, capital flow and so on, } \\
\text { the primary production elements are } \\
\text { processed and reproduced to make them } \\
\text { into products and services. [3] }\end{array}$ \\
\hline & \multirow[t]{2}{*}{ Decomposer } & Constitution & Microorganism & market \\
\hline & & function & $\begin{array}{l}\text { The complex organic matter is } \\
\text { decomposed into simple } \\
\text { inorganic substances and } \\
\text { eventually returned to the } \\
\text { environment in the form of } \\
\text { inorganic substances. }\end{array}$ & $\begin{array}{l}\text { The final products and services of the } \\
\text { communications industry are } \\
\text { "decomposed" into various forms of } \\
\text { material, and are eventually returned to the } \\
\text { external environment in the form of capital } \\
\text { and information. }\end{array}$ \\
\hline \multirow[t]{2}{*}{$\begin{array}{l}\text { Non-Bio } \\
\text { component }\end{array}$} & \multirow[t]{2}{*}{ Environment } & constitution & $\begin{array}{l}\text { The natural environment, such } \\
\text { as sunlight, air, water, soil, etc. }\end{array}$ & $\begin{array}{l}\text { The social environment such as spectrum } \\
\text { resources, natural resources, economy, } \\
\text { culture, laws and regulations, science and } \\
\text { technology, etc. }\end{array}$ \\
\hline & & function & $\begin{array}{l}\text { It continues to provide various } \\
\text { resources for the survival and } \\
\text { reproduction of organisms, and } \\
\text { regulates the ecosystem through } \\
\text { the allocation of resource } \\
\text { elements. }\end{array}$ & $\begin{array}{l}\text { It continuously provides various resources } \\
\text { for the communication industry to survive } \\
\text { and grow, and regulates the industrial } \\
\text { ecosystem through the allocation of } \\
\text { resource elements. }\end{array}$ \\
\hline
\end{tabular}

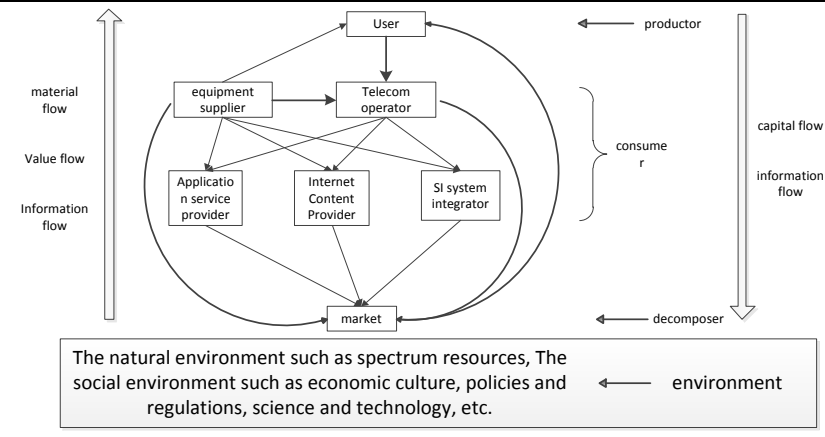

Figure I. the function map of the ecosystem of the 5G industry [4]

\section{ROLE OF RADIO MANAGEMENT IN THE 5G INDUSTRY ECOSYSTEM}

In the $5 G$ industry ecosystem, the radio management department is a kind of special member. As an non-bio factor of the $5 G$ industry ecosystem, it uses administrative, legal, economic and technical means to coordinate and deal with various kinds of Radio interference by examining, approving, 
supervising and checking various various kinds of radio. The rational and effective use of radio spectrum resources will affect the natural environment and social environment of the $5 \mathrm{G}$ industry ecosystem.

Radio management is the management of the ecological environment of the $5 \mathrm{G}$ industry ecosystem. Radio management work in the $5 \mathrm{G}$ industry ecosystem is mainly done in the following aspects:

\section{A. The Management of Ecological Resources}

Natural resources, such as sunlight, air, water, land, forest, grassland, animal, mineral, etc, are the material basis of the natural ecosystem. Without natural resources, the ecosystem will not create energy, and the ecosystem will not be maintained.

In the same way, the spectrum resource is the resource of the $5 \mathrm{G}$ industry, the material base of the $5 \mathrm{G}$ industry ecosystem, the carrier of the radio service and the application of the $5 \mathrm{G}$ industry. Without the spectrum resources, and the $5 \mathrm{G}$ will not pass the information. Radio spectrum resource management is the management of ecological resources of the $5 \mathrm{G}$ industry.

The traditional mode of spectrum resource management is to divide special bands for different services and to delineate frequency protection belts to prevent other services from interfering with the main business of the band. Although the interference between different services is effectively solved, the frequency use efficiency of this management mode is low, and the delimitation of the frequency protection band has also caused a certain waste of frequency. With the continuous development of technology and application in the emerging fields of Internet of things, Internet and industrial Internet, the demand for radio spectrum resources is increasing day by day, and the spectrum contention with other services is becoming more and more intense. The spectrum resources are facing huge gap and pressure, and the friction and collision with the existing spectrum management mode are becoming more and more significant. At the same time, the demand for information communication is getting higher and higher. The $5 \mathrm{G}$ industry must provide more high speed and higher quality communication services to maintain the development of the $5 \mathrm{G}$ industry ecosystem, which also produces more spectrum resource requirements. In order to enable the $5 G$ industry ecosystem to continue to develop and meet users' better use needs, we need to scientifically and reasonably plan the spectrum resources.

\section{B. The Management of Value Chain}

In natural ecosystems, species flow, energy flow, material circulation, information transmission and value flow are carried out through food chain among the components. In the $5 \mathrm{G}$ industry, energy flow and information transmission are realized through radio stations (value chains). Radio station management is the management of the value chain of $5 \mathrm{G}$ industry.

At present, the management mode of radio stations in China is mainly for administrative licensing, filing and license exemption. However, the wide application of radio technology, the continuous development and expansion of the $5 \mathrm{G}$ industry, the rapid spread of the Internet of things, the Internet of cars, the public mobile communication network, and so on. The demand for radio stations is increasing. All kinds of radio stations are increasing. By the end of 2017, more than 3 million 800 thousand radio stations have been licensed in China. . The pre approval process of the base station has occupied the main energy of the station managers. If we continue to use the current management mode, the cost of human resources will continue to expand. In order to reduce the further consumption of human resources, we need to explore new radio management modes and means that are in line with current and future development trends.

\section{The Management of Ecological Order}

The energy conversion and material circulation of natural ecosystems have a certain order and limit in terms of quantity, position and order. It conforms to this order and keeps a certain limit. The structure and function of the system are in a stable state, that is, the so-called ecological balance. Therefore, in order to maintain the ecological balance of natural ecosystems, we must maintain order in the natural ecosystem.

In the same way, information exchange and material circulation in the $5 \mathrm{G}$ industry must follow a certain order and limit, conform to this order, keep a certain limit, the structure and function of the system can be in a stable state, so as to maintain the ecological balance of the $5 \mathrm{G}$ industry ecosystem. 
Radio monitoring is the management of the ecological order of the $5 \mathrm{G}$ industry.

The well development of the $5 G$ industry ecosystem is inseparable from the orderly air wave order. However, with the continuous development and deepening of radio technology, the behavior of disturbing the order of radio communication is increasing. It is often illegal to set up and use radio transmitting equipment to disturb radio order. "Black broadcasting" and "pseudo base station" illegally occupy the radio spectrum resources and disrupt social and public order. The criminal activities in the radio field also show many new characteristics, such as the increasing degree of damage, the increasing number of illegal activities, and the expansion of the scope of influence. In particular, illegal acts such as black broadcasting, pseudo base station and radio jammer are used without authorization. It not only seriously interferes with the order of radio communication, but also boosts the occurrence of illegal activities such as telecommunication fraud, and some threaten the flight safety of flight, and it has serious social harmfulness. Radio communication is like road traffic, and each business is transmitted according to the allocated frequency, so that the information can be transmitted to the destination accurately. Unauthorized use or alteration of radio frequency may lead to a "crash" in radio business. Therefore, in order to effectively maintain the order of air waves and ensure the safety of the radio, we should explore more scientific and effective radio monitoring technology in combination with the development direction and characteristics of the new radio service.

\section{RADIO MANAGEMENT BASED ON ECOSYSTEM}

"Ecological system ecology" says: "for an ecosystem, the bio and non-bio parts are indispensable. Without a non-biological environment, there is no place and space for living, and no energy and material, so it is difficult to survive." In the $5 \mathrm{G}$ industry ecosystem, radio management, as the non-biological factor of the $5 \mathrm{G}$ industry ecosystem, plays a vital role in maintaining the balance of the $5 \mathrm{G}$ industry ecosystem.

In addition to exploring new administrative, legal, economic and technical means, such as spectrum resource sharing, dynamic spectrum management, wireless channel large data modeling, spectrum resource marketing configuration, Internet + station management, and real-time monitoring of radio artificial intelligence to strengthen the effective allocation of spectrum resources, standardize the legitimate use of radio stations and maintain the order of radio waves in the air to adapt to the new development situation, the radio management can be strengthened by the concept of radio ecological management:

\section{A. Overall Consciousness: Establish the Overall}

\section{Consciousness and Strengthen Overall Management}

The $5 \mathrm{G}$ industry is an ecosystem, the whole ecosystem is a destiny community, its health and sustainable development among the elements is of great significance and far-reaching impact. And the needs of the users of the $5 \mathrm{G}$ industry ecosystem services are not individual needs, but the needs of the whole human society, and the overall planning and management are needed. Therefore, the maintenance of ecological balance should have the overall consciousness. The radio managers of the $5 \mathrm{G}$ industry ecosystem need to set up the overall consciousness and the overall consciousness, and use the whole method to actively participate in the environmental governance and order maintenance of the $5 \mathrm{G}$ industry, consider the ecological development as a whole, and promote the radio spectrum management, radio station management and radio order as a whole. Management, improve the level of radio management, meet the needs of the healthy and orderly development of the $5 \mathrm{G}$ industry, promote the benign interaction between the industry and radio environment, and coordinate the development of [5].

\section{B. Innovation Consciousness: Grasp the Development}

\section{Direction and Realize Independent Innovation}

The $5 \mathrm{G}$ industry ecosystem takes the unprecedented rapid rate to carry on the update of the technology. Grasping the direction of the development of the $5 \mathrm{G}$ industry, seizing the historical opportunity of the development of the $5 \mathrm{G}$ industry, bring the China new development in the field of information and communication development, and occupy the commanding point of the development of the $5 \mathrm{G}$.

Radio management is a key element to guarantee the development of the new generation of $5 \mathrm{G}$ industry. However, the domestic technology level of radio technology is still 
relatively low, and radio monitoring and testing equipment rely heavily on imports. In the field of radio security involving national security, it is more reassuring to have its own system. The recent "ZTE" incident also alerted us that if our core technology would not be held in our hands, we would be stuck and pinched. Therefore, the development and independent innovation of the core technology of radio monitoring equipment and detection equipment are accelerated, and the localization of radio equipment is actively promoted, and it can provide a safer defense for radio management.

\section{Coordination Consciousness: Strengthen the Order Management and Maintain the Ecological Balance}

The management departments maintain the normal order of the industrial ecosystem is the basis. The $5 \mathrm{G}$ industry ecosystem cannot be separated from the radio management departments to maintain the radio order, through radio monitoring, equipment detection, interference investigation, administrative law enforcement and other maintenance of electrical wave order. Therefore, we should strengthen the supervision of the radio management department for the $5 \mathrm{G}$ industry ecosystem, avoid the supervision mode of "headache medical head pain", and should form a comprehensive and feasible long effect mechanism, improve the comprehensive supervision mechanism for the production, marketing and use of the whole industry chain of the $5 \mathrm{G}$ industry, and create a harmonious and orderly wireless communication environment.

The rule of law is still one of the important means of radio management. For radio management, it is difficult to apply a number of policies for individual enterprises and individual systems. It is necessary to formulate corresponding policies according to the characteristics of the ecosystem environment of the $5 \mathrm{G}$ industry, for radio frequency use, radio station management, radio interference complaints, radio tube management law enforcement, radio equipment detection and so on. We need to further study and formulate relevant policies, improve the supporting system, further strengthen and improve the system of radio management legal system, and maintain the ecological system environment order and balance in the $5 \mathrm{G}$ industry.

\section{Open Awareness: Strengthen the Participation of}

Multiple Stakeholders and Achieve Common Governance

The healthy development of any organization is indispensable for effective governance. However, the ecological system is a new and loose organization. In addition to the establishment of the corresponding ecological system, the commercial platforms have not established the ecological system governance, resulting in the barbarous growth and sudden collapse of many ecosystems, which seriously damage the interests of many parties. In order to promote the healthy and orderly development of the $5 \mathrm{G}$ industry ecosystem, the government should give full play to the administrative power, request the communication enterprise to introduce the multi stakeholder governance model, realize the multi-party co-governance radio management, create a new pattern of ecological system maintenance and management of the $5 \mathrm{G}$ industry shared by the co governance.

\section{E. Sharing Consciousness: Building the Destiny Community and Strengthening Global Cooperation}

The industry and use of information and communication have the characteristics of globalization, and radio management has the attributes of globalization. For radio management, we should make full use of the international organization platform such as ITU and APT, strengthen international coordination and rely on the international cooperation mechanism on the basis of our own interests, strengthen international cooperation, win mutual benefit, improve international vision, and build up the fate of the $5 \mathrm{G}$ industry ecosystem.

\section{F. Diversity Consciousness: Maintain Diversity and}

\section{Achieve Precise Management}

Diversity is an important indicator of the healthy development of the ecosystem, and also applies to the $5 \mathrm{G}$ industry ecosystem. The richer the diversity of ecosystems is, the more complex their components and their corresponding business types are, and the more stable the ecosystem is. With the rapid development of $5 \mathrm{G}$ industry, the ecosystem of $5 \mathrm{G}$ industry will be more complicated and diverse. To maintain the ecological system of the $5 \mathrm{G}$ industry, that is to maintain the diversity of the ecosystem, based on the existing development, taking into consideration the various factors in the future, 
combining the development of the industry and adopting the appropriate scientific analysis methods, the practical radio management methods are put forward to provide long-term planning for the medium and long term development of the $5 \mathrm{G}$ industry. . Reasonable demand analysis of frequency demand, can provide the basis for the radio management department to formulate the medium and long term planning of the frequency needs.

Because the application of the 5G industry is diversified, individualized and differentiated, different application scenes have great differences in frequency selection, bandwidth demand, transmission power and application scene. It is necessary to consider the characteristics of radio wave propagation and industry trend, and carry out more detailed demand forecast. In the case of the limited total spectrum resources, the basic demand and the key development direction are guaranteed, and various technologies are encouraged to share the spectrum, integrate the fragmented and scattered frequency resources, realize the accurate supply of the spectrum resources, improve the supply quality, realize the structural reform of the supply side of the radio management, and promote the information and communication production. The structure of the industry is more scientific and reasonable, so as to promote the sustained and healthy development of the $5 \mathrm{G}$ industry.

\section{CONCLUSION}

With the rapid development and rapid change of the $5 \mathrm{G}$ industry, the speed of the iteration of the technology update is accelerated, the radio management work should follow the development of the times, adapt to the new situation and the new background, the transformation and upgrading of the management means. The concept of the ecosystem consciousness of radio management provided by this article opens another management thought for radio management. It is believed that it can provide useful reference for the exploration of new radio management methods, and to safeguard the balance of the $5 \mathrm{G}$ industry ecosystem.

\section{ACKNOWLEDGMENT}

This work was supported by the National Science and Technology Major Project under Grants No. 2015ZX03002008.

\section{REFERENCE}

[1]GUO Ning, LIANG Xiong-jian. An analysis of the industrial structure of communications based on the ecosystem [J]. The Journal of Beijing University of Posts and Telecommunication (Social Sciences Edition ), 2005(2):39-42.

[2] HUANG Yong, CAO Li-jun. Telecommunication Industry Ecosystem and its Development Measures[J]. Future and Development, 2011(3):32-35.

[3]CHEN Jian-xuan, YANG Jian-mei. Research on Enterprise Cluster Based on Ecosystem [J]. Technoeconomics \& Management Research, 2004(5):22-23.

[4]GUO Ning. The Study on the Ecosystem of Communications Industry[D]. Beijing University of Posts and Telecommunication, 2005. http://www.wanfangdata.com.cn/details/detail.do?_type=degree\&id=Y9 46241.

[5] QIAN Pin-fan, QIAN Peng-zhan. Platform Ecosystem's Essence of Development and Policy Implications[J]. Journal of Chongqing University of Technology(Social Science), 2017(2):1-9. 